\title{
JUDICIAL ENFORCEMENT OF AGREEMENTS TO SHARE WINNING LOTTERY TICKETS
}

\author{
MatTHEW J. GRIES \\ INTRODUCTION
}

Every year, it seems, another state enacts a state-sponsored lottery. ${ }^{1}$ Before doing so, a great debate over the pros and cons of lotteries inevitably occurs. Those in favor of having a lottery point to its proven money-making capacity and argue that money from their state is currently flowing to border states that have lotteries. Those opposed argue that lotteries are gambling and therefore immoral, that lotteries are unfair because they act as a

1. Thirty-seven states and the District of Columbia currently have state-sponsored lotteries. See ARIZ. Rev. STAT. ANN. \$§ 5-501 to 5-525 (1995); CAL. Gov'T CODE \$\$ 8880-8880.72 (West 1992 \& Supp. 1995); CoLO. REV. STAT. \$§ 24-35-201 to 24-35-221 (1988 \& Supp. 1994); CONN. GEN. STAT. ANN. \$§ 12-557b to 12-578 (West 1993); Del. CODE ANN. tit. 29, §§ 4801-4835 (1991 \& Supp. 1994); D.C. CODE ANN. \$§ 2-2501 to 2-2537 (1994); FLA. STAT. ANN. \$§ 24.101-24.123 (West 1988 \& Supp. 1995); GA. CODE ANN. \$§ 50-27-1 to 50-27-55 (1994); IDAHO CODE §§ 67-7401 to 67-7452 (1989 \& Supp. 1994); ILL. ANN. STAT. ch. 20, para. 1605/1-1605/28 (Smith-Hurd 1993 \& Supp. 1994); IND. CODE ANN. \$§ 4-30-1-1 to 4-30-19-4.2 (Burns 1990 \& Supp. 1994); IOWA CODE ANN. \$§ 99E.1-99E.34 (West Supp. 1994); KAN. STAT. ANN. $\$ \S 74-8701$ to 74-8732 (1992); KY. REv. STAT. ANN. \$§ 154A.010-154A.990 (BanksBaldwin 1992); LA. REv. STAT. ANN. \$§ 47:9000-47:9081 (West Supp. 1993); ME. REv. STAT. ANN. tit. 8, \$§ 371-387 (West Supp. 1994); MD. CODE ANN., STATE Gov'T §§ 9-101 to 9-125 (1994); MAss. ANN. LAwS ch. 10, §§ 22-58 (Law. Co-op. 1988 \& Supp. 1993); Mich. CoMP. LAWS ANN. §§ 432.1-432.47 (West 1978 \& Supp. 1994); MINN. STAT. ANN. §§ 349A.01-349A.15 (West 1990 \& Supp. 1994); Mo. ANN. STAT. $\S \S 313.200-313.350$ (Vernon Supp. 1993); MONT. CODE ANN. \$§ 23-7-202 to 23-7-412 (Supp. 1994); NEB. Rev. STAT. §§ 9-801 to 9-842 (1991 \& Supp. 1993); N.H. REv. STAT. ANN. \$§ 287-F:1 to 287-F:19 (1987); N.J. STAT. ANN. \$§ 5:9-1 to 5:9-25 (West 1988 \& Supp. 1994); N.Y. TAX LAW $\S \S 34-1600$ to 34-1619 (McKinney 1987 \& Supp. 1994); OHIO REv. CODE ANN. \$\$ 3770.01-3770.99 (Baldwin 1993); OKLA. STAT. ANN. tit. 21, §§ 1051-1068 (West 1983 \& Supp. 1994); OR. REV. STAT. §§ 461.010-461.725 (1992); PA. STAT. ANN. tit. 72 §§ 3761-1 to 3761-15 (Supp. 1994); R.I. GEN. LAWS §§ 42-61-1 to $42-61-17$ (1993 \& Supp. 1994); S.D. CodifiEd LAws ANN. §§ 42-7A-1 to 42-7A-64 (1991 \& Supp. 1994); TEX. GOV’T CODE ANN. \$\$ 466.001-466.408 (West Supp. 1995); VT. STAT. ANN. tit. 31, §§ 651-678 (1986 \& Supp. 1994); VA. CODE ANN. \$§ 58.1-4000 to 58.1-4028 (Michie 1991 \& Supp. 1994); WASH. REv. CODE ANN. $\S \S 67.70 .010-67.70 .905$ (West 1985 \& Supp. 1993); W. VA. CODE $\S \S 29-22-1$ to 29-22-28 (1992 \& Supp. 1993); WIS. STAT. ANN. §§ 565.01-565.50 (West Supp. 1993). 
regressive tax, or that lotteries encourage the poor to squander money that they can ill afford to waste.

One hazard of lotteries often overlooked, however, is that winning tickets potentially encourage the destruction of families, friendships, and working relationships and, in the process, the wasting of judicial resources. Often when people buy tickets, they have promised, have an understanding, or have an agreement with a family member, friend, or co-worker to share any winnings. When some of these people win, however, they refuse to share as promised, either because greed takes over or because they feel that the other party is not entitled to anything; the money takes precedence over the relationship. The other party, however, may feel that he had a contract to share the winnings and thus is being cheated. Litigation then ensues, and whatever relationship the parties had is ruined. ${ }^{2}$

From a policy perspective, it makes sense to limit these unfortunate outcomes if at all possible. This could be done in two ways.

2. A good example of this phenomenon is currently occurring in North Carolina. A 20-year friendship was destroyed when one member of a lottery pool made up of retired longshoremen refused to share the proceeds of a $\$ 9$ million winning Virginia lottery ticket. Walter Cole claimed that he had bought the ticket with his own dollar and not with the pool's funds. Tom Campbell, Judge Halts Lotto Payment, RICHMOND TimesDISPATCH, Sept. 18, 1992, at B7. The result has been extensive litigation. Initially, a judge in the Chesapeake Circuit Court in Virginia issued a temporary injunction barring the Lottery Department from paying Cole the first installment of the winnings until after a hearing was held on the issue of jurisdiction. Suit Asks Lotto Cronies Be Denied Winnings Share, RICHMOND TIMES-DISPATCH, Oct. 8, 1992, at B4. Before that hearing could be held, however, Cole filed suit in Pasquotank County, North Carolina, asking that he be awarded the jackpot. Virginia Lotto Payoff Prompts a 2nd Lawsuit Among Friends, ChARLOTTE ObSERVER, Oct. 8, 1992, at 3C. That court held that any agreement that might have existed between the men could not be enforced because the agreement violated North Carolina laws against gambling. Judge Rejects Claim by 4 Men to Lotto Prize, Richmond Times-DisPATCH, Dec. 10, 1992, at B4. The North Carolina case was subsequently appealed by the four men seeking a portion of the winnings. The Chesapeake Circuit Court judge who had granted the initial injunction responded by ruling that the injunction would continue and that he would refrain from ruling on the jurisdictional issues until the North Carolina appellate court issued its decision. Payoff to Wait for N.C. Ruling, RICHMOND TIMES-DISPATCH, Apr. 22, 1993, at B4. The North Carolina decision was subsequently affirmed by both a North Carolina appellate court and the North Carolina Supreme Court. The case then returned to the Virginia judge, who ruled that North Carolina law governed the agreement because it was made in North Carolina and therefore that the decision of the North Carolina courts was final. The judge also reasoned that even if he did have jurisdiction, the agreement would still be unenforceable because Virginia law holds gambling contracts unenforceable and a lottery pooling agreement is such a contract. This decision will likely be appealed. Marc Davis, Lotto Winner Need Not Share with His "Friends," Virginian-PILOT, Sept. 2, 1994, at A1. 
First, courts could refuse to enforce any promise to share lottery winnings. This policy would certainly save judicial resources, and it might also save some relationships. If lottery players knew that such promises were unenforceable, they might not make them, and even if they did, their promisees might not rely on them too heavily. Second, courts could refuse to enforce any promise to share lottery winnings not accompanied by some sort of written agreement. This policy also would save judicial resources as well as relationships because it would encourage lottery players to consider seriously the implications of any promises.

These courses of action may have support as policy, but whether there is any legal support for the judiciary's taking such action is another question. This Note analyzes the law of contracts and argues that there are several arguments to support the first option above. It further argues that with an ambitious step forward, there is also support for requiring written agreements before courts will entertain disputes over lottery ticket ownership.

Part I begins with an examination of a New York case that exemplifies the lottery pooling disputes that have been litigated. This Part shows that even in extreme cases, courts do not hesitate to analyze lottery sharing agreements as contracts and questions whether they should do so. Part II explores the unenforceability of gift promises and social engagements. It argues that courts should analogize agreements to share lottery winnings to these types of undertakings and thus find them unenforceable. Part III explains that while it may be possible to dismiss agreements to share lottery winnings as gifts or social engagements, it is not necessary to do so to hold them unenforceable. This Part asserts that the underlying rationale behind the unenforceability of both gift promises and promises to participate in social engagements is their lack of reliability. ${ }^{3}$ It then argues that lottery pooling arrangements are equally unreliable and thus should not be enforceable. This Part concludes by arguing that such reliability could be supplied by requiring a writing for lottery pooling agreements. Such a writing

3. The term "reliability" in this Note is not meant to include the issue of whether there is reliable evidence of an agreement. Instead, when a promise is reliable, it is the type of promise on which a promisor should know his promisee likely will rely and is the type of promise on which society has determined a promisee is justified in relying. See infra Part III. 
would indicate that the parties consciously chose to enter a judicially enforceable contract.

\section{A Representative CASE}

A case that raises the issue of whether promises to share lottery winnings should be enforced as contracts is Pando v. Fernandez. ${ }^{4}$ Stuck in the New York court system for several years, the dispute between Christopher Pando and Dayal Fernandez was over their respective entitlements to a $\$ 2.8$ million prize won in the New York lottery. While the evidentiary problems that faced the courts are interesting, that is not why this case is presented here. Instead, this case is introduced to demonstrate that lottery sharing agreements are quite different from the commercial dealings that are universally regarded as contracts; courts, however, do not hesitate to assume that such agreements rise to the level of a contract.

Christopher Pando, the plaintiff, was a sixteen-year-old friend of the son of the defendant, Dayal Fernandez. He brought suit against Fernandez after she won $\$ 2.8$ million in the New York lottery, alleging that Fernandez had promised to share her lottery winnings with him equally. He claimed that when he was fourteen years old, ${ }^{5}$ he and his friend's mother had agreed to participate together in a lottery ticket purchasing endeavor. ${ }^{6}$

Pando explained that Fernandez believed that he was a deeply religious person because of his strong belief in St. Eleggua and that his prayers could make her a winner in the lottery. Because she felt this way about him, he contended, she promised that if he would purchase lottery tickets with $\$ 4$ that she gave him and if he would also select the numbers, she would give him half of the winnings of any of the tickets he purchased. However, Fernandez refused to share her winnings with Pando when she won the $\$ 2.8$ million prize. She denied that she had ever asked Pando to buy tickets or pick numbers for her and that an agreement ever existed to share her winnings with him.?

4. 485 N.Y.S.2d 162 (Sup. Ct. 1984), rev'd, 499 N.Y.S.2d 950 (App. Div.), modified, 508 N.Y.S.2d 8 (App. Div. 1986).

5. Pando, 499 N.Y.S.2d at 951.

6. Pando, 485 N.Y.S.2d at 164.

7. Id. 
In the initial action, the New York Supreme Court assumed, for the sake of argument, that Pando's explanation of the agreement between Fernandez and him was true. The court concluded that based on Pando's testimony, the contract was made up of four conditions precedent: " 1 . He was to buy the lottery tickets with defendant's money[;] 2 . He was to select the numbers[;] 3 . He was to pray to the saint[; and] 4. The saint was to make his selection win." Based on this contract, the court held that Pando could not collect because it was impossible for him to prove that St. Eleggua caused the ticket to win. The opinion discussed the philosophies involved, quoted from the Bible, provided examples, and ultimately concluded that "[e]stablishing that [the saint made the ticket win] is not susceptible to forensic proof." "The court then granted the defendant's motion for summary judgment. ${ }^{10}$

In 1986, the decision of the trial court was overturned on appeal. ${ }^{11}$ The appellate court agreed that saintly intervention could not be proven but stated that it was "far from evident that the alleged agreement require[d] such intervention as a condition of enforceability." ${ }^{\prime 2}$ The court stated that in three places in the record, which were not cited by the lower court, Pando described the agreement without the condition that the saint actually intervene: "According to these versions, plaintiff was obligated only to use his best efforts to enlist Saint Eleggua's help in exchange for which defendant agreed to pay for the tickets and split the prize should it be won."13 Therefore, the court concluded that the lower court's granting of summary judgment was inappropriate because there remained a material question of fact. ${ }^{14}$

8. Id. at 169 .

9. Id. at 168. In an amusing note, the judge explained his attempt to determine the identity of Pando's St. Eleggua. The closest name he found was St. Eligius, the patron saint of goldsmiths, who "showered his riches on the poor" and possessed the gift of miracles. The judge surmised that it was "[n]o wonder defendant sought to invoke his aid as the means to overwhelming riches!" Id. at 167. It is more likely, however, that Pando's saint was Elleggua, one of the "seven African powers" revered in some western hemisphere religions that have their origins in Africa, such as voodoo. LUISAH TEISH, JAMBALAYA 113 (1985). Legend has it that "[w]hen pleased, Elleggua can . . b bestow unexpected good fortune." Id. at 116.

10. Pando, 485 N.Y.S.2d at 170.

11. Pando v. Fernandez, 499 N.Y.S.2d 950, 953 (App. Div. 1984), noodified, 508 N.Y.S.2d 8 (App. Div. 1986).

12. Id. at 952 .

13. Id.

14. Id. at 952-53. Although not the focus of this Note, the evidentiary problems 
Although Pando had difficulty explaining the terms of his agreement with Fernandez, although the agreement was oral, and although the agreement was extremely informal, both the trial court and the appellate court in this case did not even pause to consider whether the agreement should be analyzed as a contract; they did so automatically. The question that this case raises with its extreme facts is whether they should have. This Note argues that courts should not treat such agreements as contracts.

\section{Gift Promises, Social ENgagements, AND THE UNENFORCEABILITY OF AGREEMENTS TO SHARE LOTTERY WINNINGS}

Support for not enforcing any lottery sharing agreements is found in the treatment of gratuitous promises and social engagements in the law of contracts. These promises traditionally have been unenforceable under contract law, and if courts were to analogize agreements to share lottery winnings to these types of promises, they also would be unenforceable. This Part argues that courts should do just that. Using a combination of these concepts, courts should deem all lottery winnings sharing agreements unenforceable.

\section{A. Gift Promises}

Gift promises have traditionally not been enforced by courts because they lack the elements of a contract. For an agreement to be deemed a contract, there must be an offer, an acceptance of that offer, and consideration. ${ }^{15}$ The Restatement (Second) of Contracts defines an offer as "the manifestation of willingness to enter into a bargain, so made as to justify another person in understanding that his assent to that bargain is invited and will conclude it." ${ }^{\text {"16 }}$ An acceptance is the assent to that bargain. Consideration is defined as a performance or return promise for which a party

associated with this case were quite severe. First, did the agreement call merely for prayer or for the prayer to be answered? Further, even if it were assumed that a contract existed requiring Pando to prove only that he prayed, how would a jury determine if Pando actually prayed or if he merely went through the motions?

15. "[T]he formation of a contract requires a bargain in which there is a manifestation of mutual assent to the exchange and a consideration." RESTATEMENT (SECOND) OF CONTRACTS $\S 17(1)$ (1979).

16. Id. $\S 24$. 
to the contract has bargained. ${ }^{17}$ Such a performance or return promise will be deemed to have been bargained for "if it is sought by the promisor in exchange for his promise and is given by the promisee in exchange for that promise." 18

Promises to make gifts lack these required elements. No offer is made, there is thus no offer to accept, and there is no consideration from the promisee. A gift promise is not an invitation to enter into a bargain because there is no exchange sought by the promisor, and because no exchange is sought, consideration for the promise is not present. "Whether or not a proposal is a promise, it is not an offer unless it specifies a promise or performance by the offeree as the price or consideration to be given by him."19

Because a gift promise does not contain the required bargain element, it does not rise to the level of an enforceable contract even if the promise is a conditional one. ${ }^{20}$ In other words, a promise to make a gift is not treated as a bargain even if "the terms of [the] gift impose a burden on the donee as well as the donor." 21 For example, if "A promises B $\$ 100$ if B goes to college [and if] the circumstances give $B$ reason to know that $A$ is not undertaking to pay $B$ to go to college but is promising a gratuity, there is no offer." ${ }^{\prime 22}$ As a leading authority of contract law explains,

Very often a promisor who intends to promise a gratuity makes the performance of his undertaking dependent upon the happening of some event, the happening of which may be detrimental to the promisee or beneficial to the promisor. However, in such a case, there is no sufficient consideration to make the promise binding, since the detriment or benefit suffered or received is merely the motive or occasion for the contemplated gift; at most it is the condition of a gratuitous promise, rather than the price for a promise bought and paid for. ${ }^{23}$

17. Id. $\S 71(1)$.

18. Id. $\S 71(2)$.

19. Id. $\S 24 \mathrm{cmt}$. b.

20. 1 ARTHUR L. CORBIN, CORBIN ON CONTRACTS $\S 151$, at 671-72 (1963); JoHN E. MURRAY, JR., GRISMORE ON CONTRACTS $\S 59$, at 91 (rev. ed. 1965) [hereinafter GRISMORE].

21. RESTATEMENT (SECOND) OF CONTRACTS $\$ 71 \mathrm{cmt} . \mathrm{c}$ (1979).

22. Id. $\$ 24 \mathrm{cmt} . \mathrm{b}$, illus. 2.

23. GRISMORE, supra note $20, \S 59$, at 91 . 
The most famous case dealing with such a conditional gift promise is Kirksey $v$. Kirksey. ${ }^{24}$ In that case, a brother-in-law wrote to his widowed sister-in-law that if she would "come down and see me, I will let you have a place to raise your family ... [because] I want you and the children to do well." ${ }^{25}$ Soon after receiving the letter, the sister-in-law abandoned her residence and moved the sixty or seventy miles to her brother-in-law's residence. $\mathrm{He}$ put her into a comfortable home and provided her with land to cultivate. Several years later, however, he forced her to leave, and in response, she brought suit for breach of contract. ${ }^{26}$ The court held that the promise was a mere gratuity, even though it was conditional, and that therefore an action in contract did not lie for its breach. ${ }^{27}$

\section{B. Agreements to Share Lottery Winnings as Gratuities}

Many of the promises to share winnings made by purchasers of lottery tickets are simply gift promises and are thus unenforceable. A court, for example, would not enforce a naked promise to a friend that if the promisor ever won the lottery, he would split the winnings with his friend. This concept can be stretched further to find promises to share lottery winnings unenforceable even when the friend must do something before the winner will share.

A case in which the court should have proceeded with such a conditional gift analysis is Fitchie v. Yurko. ${ }^{28}$ In 1989, Richard Yurko won a $\$ 100,000$ prize in the Illinois lottery but had only a fraction to show for it two years later. A court held that he had entered into an agreement with the owner and two customers of a coffee house where he bought the winning ticket and that therefore he had to share the prize with them..$^{29}$

Although disputed, the facts in this case were simple. Yurko frequently came into plaintiff Phyllis Huisel's service station and coffeehouse to have a meal and socialize. While there, he often would play the lottery with tickets purchased from Huisel's

\footnotetext{
24. 8 Ala. 131 (1845).

25. Id. at 132 .

26. Id.

27. Id. at 133.

28. 570 N.E.2d 892 (Ill. App. Ct. 1991).

29. Id. at $900-01$.
} 
shop. $^{30}$ On one such visit, Yurko bought his $\$ 100,000$ winning ticket.

The plaintiffs in this case, two customers and Huisel, testified that Yurko entered into an agreement with them on that day to share his winnings. Yurko allegedly bought numerous tickets and asked the plaintiffs to help him scratch them off. They claimed that "Yurko indicated to them that if they would help him scratch off the lottery tickets they would be his partners and would share in any winnings which resulted from those tickets." ${ }^{\prime 31}$ One of the plaintiffs scratched off the $\$ 100,000$ winning ticket, and Yurko placed the initials of the plaintiffs on the back of the ticket along with his name. He said he did this to remember who had helped him scratch the tickets because he wanted to give them something for helping him. The plaintiffs said he did this because they had an agreement to share the winnings equally. ${ }^{32}$

The appellate court upheld the trial court's conclusion that the "parties had formed a partnership of some sort" and held that "the arrangement between defendant and plaintiffs constituted a joint venture." 33 The court stated that all the evidence "warrants the conclusion that all the parties intended and agreed to the joint pursuit of a single enterprise, i.e., a lottery prize." ${ }^{34}$ The court concluded that Yurko offered to enter into such an enterprise when he stated he would share prizes won in return for the plaintiffs' help scratching the tickets and that the plaintiffs accepted by so scratching. The consideration given by the plaintiffs was that they "expended their time and energy and put forth effort to scratch the tickets." 35

Objectively analyzed, this case is not much different from Kirksey ${ }^{36}$ and could have been disposed of in a similar way. Yurko paid for the tickets, and all that the plaintiffs did was help him scratch them off. The court, laboring to find a contract, apparently believed that Yurko bargained away his potential future winnings by conditioning his sharing on this act. ${ }^{37}$ But the events

30. Id. at 894 .

31. Id. at 895 .

32. Id.

33. Id. at 899 .

34. Id. at 900 .

35. Id.

36. Kirksey v. Kirksey, 8 Ala. 131 (1845).

37. If scratching the tickets was consideration for Yurko's promise to share, as the 
at the coffee shop could just as easily have been characterized as a conditional gift promise and should have been so analyzed. Yurko bought the lottery tickets, promised to share the winnings with his social companions as a gift, and then socially interacted with them by including them in the game. He wanted to have a good time, wanted his friends to have a good time, and promised to share his winnings to reach that goal. His return was seeing his acquaintances happy, just as the return usually is when a gift is given. $\mathrm{He}$ was not entering into a commercial deal to hire scratchers.

While it is true that the court should have characterized Yurko's promise as a gift and should do likewise in future cases of this sort, it is not true that all lottery sharing agreements can be characterized this way. This is because promises to share lottery winnings frequently are accompanied by the pooling of funds to purchase the tickets. When both the purchaser of a ticket and his friend contribute money to the ticket's purchase, consideration is present and gift treatment is inappropriate. Thus, the concept of gift promises serves only a limited role in concluding that all lottery sharing agreements should be unenforceable. The introduction of this concept, however, also serves another purpose. As discussed below, the underlying rationale behind the unenforceability of gift promises supports the conclusion that lottery pooling agreements should be unenforceable even when consideration is present. ${ }^{38}$

\section{Social Engagements}

Although not all lottery sharing agreements can be characterized as gifts, there is support in contract law for finding them unenforceable. This support is found in the treatment of social engageinents. Social engagements have generally been unenforceable as contracts, ${ }^{39}$ and pooling agreements also would be unenforceable if characterized in this manner.

court determined, then it would be irrelevant if the scratching was worth much less than Yurko's promise. This is because courts consider the existence of consideration, but generally do not inquire into the adequacy of consideration. See RESTATEMENT (SECOND) OF CONTRACTS $\S 79 \mathrm{cmt}$. c (1979). Thus, it is irrelevant that the scratching in this case was not worth much. Instead, what is relevant is whether Yurko sought it in exchange for his promise or merely as a condition of his promise.

38. See infra Part III.

39. See infra text accompanying notes $46-55$. 
A classic example of a dispute over a social engagement promise recently made its way into the popular press and raised the ire of many people who think that society has become too litigious. ${ }^{40}$ The case involved Tomontra Mangrum, a fifteen-yearold girl, who brought suit against the boy who was supposed to take her to her high school prom, but did not. She claimed that because he breached their agreement to go to the prom together, she suffered damages of $\$ 49.53$ ( $\$ 26$ for shoes that she could not return, $\$ 23$ for hairstyling, and 53 cents for flowers for her hair). ${ }^{41}$ Marlon Shadd, the defendant, countered that he told Tomontra five days before the prom that he had fractured his ankle and would not be able to take her. ${ }^{42}$ Nevertheless, he settled the case to, in the words of his attorney, "get rid of it." 43

Many people were infuriated by this case. As one writer put it, "There can be only one group of people delighted to hear this story. They are called lawyers." 44 This anger is an interesting response to a simple suit to enforce a contract, ${ }^{45}$ and it suggests there was something quite different about this case that made people think it was not appropriate for the judicial system to determine its outcome. It is hard to label what that something is, but the authorities on contracts have suggested several explanations.

Although the prom case never came to court, the cases of this sort that have been decided, although few, suggest that courts will not enforce promises for social relations. ${ }^{46}$ The authorities on

40. For a thorough understanding of all the facts of the case and a sampling of the controversy and criticisms it raised, see Andrew Blum, Prom-ises, Prom-ises, NAT'L L.J., May 29, 1989, at 43; Art Buchwald, Suing Has Replaced Suffering for Teens, CHI. TRIB., May 23, 1989, at C17; Clarence Page, Filing Suit Means Never Saying "Sorry", ST. LouIS Post-DisPatch, Aug. 19, 1989, at 3B; Clarence Page, If Not a Prom Date, Maybe a Court Date Suits the Vengeful, CHI. TRIB., May 17, 1989, at C19 [hereinafter Page, If Not a Prom Date]; \$81.28 Settles a Prom Date That Wasn't, CHI. TrIB., June 21, 1989, at C4; Pain, Suffering and the Prom, WASH. Posr, May 15, 1989, at A8.

41. Pain, Suffering and the Prom, supra note 40, at A8.

42. Id.

43. \$81.28 Settles a Prom Date that Wasn't, supra note 40 , at C4.

44. Page, If Not a Prom Date, supra note 40, at C19.

45. Technically, the elements of a contract may have been present. Recall that consideration need not be performance but can be a return promise that is "sought by the promisor in exchange for his promise and is given by the promisee in exchange for that promise." RESTATEMENT (SECOND) OF CONTRACTS $\S 71(2)$ (1979).

46. See, e.g., O'Reilly v. Mitchell, 148 N.Y.S. 88, 89 (Sup. Ct. 1914) (holding that the "remarkable proposition" that a contract results from an ante-election promise by a politician to voters must be rejected); Mitzel v. Hauck, 105 N.W.2d 378, 380 (S.D. 1960) (holding that to find a contract in an agreement between two men to go on a hunting 
contracts explain these results in a variety of ways. Corbin explains that it is not true that parties to agreements must consciously intend to effect legal relations to make an enforceable contract. Indeed, he contends that agreements to enter into business transactions are enforceable even if the parties involved do not know that courts of law exist. Thus, the fact that parties involved in social engagement agreements do not consciously intend their agreements to be judicially enforceable is not determinative of the agreement's unenforceability. However, he explains, actual "expressions of intention" as to legal relations are material in determining whether a contract exists. ${ }^{47}$ In this respect, custom becomes important. To distinguish between enforceable contracts and unenforceable social engagements, he suggests the following:

1. If the subject matter and terms of a transaction are such as customarily have affected legal relations and there is nothing to indicate that the one now asserting their existence had reason to know that the other party intended not to affect his legal relations, then the transaction will be operative legally. 2 . If the subject matter and terms are not such as customarily have affected legal relations, the transaction is not legally operative unless the expressions of the parties indicate an intention to make it so. ${ }^{48}$

Farnsworth agrees that "there is no requirement that one intend or even understand the legal consequences of one's actions." ${ }^{49}$ However, if one expresses his intention not to be legally bound, he is not bound. Thus, one need not express his intention to be bound in order to be bound; if one expresses his intention not to be bound, however, one is not bound. Such intention need not be expressly indicated in every case, however. Farnsworth explains that "[c]ircumstances, rather than words, may also indicate a party's intention not to be bound." ${ }^{50}$ Family and social agree-

trip and to use the car of one rather than the other "would transcend reality" (quoting Scotvold v. Scotvold, 298 N.W. 266, 272 (S.D. 1941))); Balfour v. Balfour, [1919] 2 K.B. 571,578 ("There are agreements which do not result in contracts .... The ordinary example is where two parties agree to take a walk together, or where there is an offer and an acceptance of hospitality. Nobody would suggest in ordinary circumstances that those agreements result in what we know as a contract .....").

47. 1 CORBIN, supra note $20, \S 34$, at 138 .

48. 1 id. (footnotes omitted).

49. 1 E. Allan Farnsworth, Farnsworth ON CONTRACTS $\$ 3.7$, at 172 (1990).

50. 1 id. at 173 . 
ments, he argues, are often surrounded by such circumstances, and in those cases, such agreements are judicially unenforceable. ${ }^{51}$

Grismore concurs that an intention to be legally bound by an agreement is not a prerequisite to judicial enforcement but that expressions of intention are important. ${ }^{52}$ Like Corbin and Farnsworth, however, he explains that social engagements are unenforceable even though an expression of intent not to be bound is not explicitly made. $\mathrm{He}$ asserts that such promises are judicially unenforceable "because in such a case it is fair to say that had the parties thought about the matter at all, it is quite clear they would have regarded such an engagement as binding only in honor."53 Grismore does not insist that an intention not to be bound actually exist and instead is willing to assume it exists based on the type of promise involved.

The Restatement (Second) of Contracts also addresses this topic, stating that intention to be legally bound is not necessary for judicial enforcement. ${ }^{54}$ However, social engagements remain unenforceable because "the normal understanding is that no legal obligation arises, and some unusual manifestation of intention is necessary to create a contract." ${ }^{35}$

\section{Lottery Pooling Agreements as Agreements to Engage in a Social Activity}

Most lottery pooling agreements are in essence social engagements and therefore should be unenforceable. The parties involved in these agreements are simply agreeing to participate in a social activity together: the playing of a game. However, for some reason, courts have not hesitated to elevate the social activity of playing the lottery to commercial transaction status.

For illustrative purposes, consider Pearsall $v$. Alexander, ${ }^{56}$ in which a winning lottery ticket worth $\$ 20,000$ ended a twenty-fiveyear friendship. Harold Pearsall and Joe Alexander routinely met twice a week after work and jointly purchased a "package," which consisted of orange juice, a half-pint of vodka, two cups, and two

51. 1 id. at $174-75$.

52. GRISMORE, supra note $20, \S 19$, at 20 .

53. Id. at 22 .

54. RESTATEMENT (SECOND) OF CONTRACTS § 21 (1979).

55. Id. \& $21 \mathrm{cmt}$. $\mathrm{c}$.

56. 572 A.2d 113 (D.C. 1990). 
lottery tickets. They would then return to Alexander's home, where they would scratch off the tickets, drink screwdrivers, and watch television. ${ }^{57}$

The men did not follow this routine exactly on the day the winning ticket was purchased. On that day, Alexander claimed not to have money for tickets, so Pearsall bought the "package" with his own money. Pearsall asked Alexander if he was "in on it," however, and Alexander said he was. ${ }^{58}$ Alexander scratched off both tickets, but they proved to be worthless. Alexander, after coming into some money, returned to the store later that evening and bought another "package," this time entirely with his own funds. Pearsall grabbed one of the tickets and scratched it, but it was not a winner. Alexander scratched the other ticket and found that it was a $\$ 20,000$ winner..$^{59}$ Alexander subsequently cashed in the ticket and refused to give Pearsall any of the prize. ${ }^{60}$

The appellate court, in its reversal of the lower court's dismissal of the case, determined that "an agreement existed between Pearsall and Alexander to share equally in the proceeds of the winning ticket at issue." fact that each party let the other scratch tickets that were purchased with only one party's funds and on its finding that they had a "long-standing pattern of similar conduct." produced "mutual promises to share in the proceeds," and these mutual promises were "adequate consideration" to sustain a contract. ${ }^{63}$

The court stretched to find a contract in this case. Because there was no actual pooling of funds to buy the ticket, the court instead found consideration by stating that the pattern of conduct suggested mutual promises. However, Alexander and Pearsall were simply agreeing to engage in a social endeavor. Consider, for example, if Alexander had bought a "package," but had refused to share the vodka with his friend even though there was a promise to do so and a return promise to help drink it. A court of law probably would not have enforced that "contract" because the

\footnotetext{
57. Id. at 114 .

58. Id.

59. Id.

60. Id. at 115 .

61. Id. at 117 .

62. Id.

63. Id. at 118.
} 
promise to share the vodka, like a promise to go on a date, was simply a promise to engage in a social activity.

Why is an agreement to engage in the social activity of playing the lottery any different? The answer might be that courts believe that when people actually pool their funds to buy tickets, the expectation becomes that the agreement is enforceable. But that may not realistically reflect the expectations of such parties, and it is instead likely that the large amounts of money involved when tickets turn out to be winners have swayed the courts toward enforcement even though the parties have no such expectation.

To understand why no such expectation exists, consider a pooling arrangement in which each week a different person has the duty of playmg the same set of numbers for the pool. On the week $X$ is supposed to play the numbers, he forgets; as Murphy's Law would have it, those numbers are subsequently drawn. The prize would have been $\$ 1$ million. If the other members of the pool sue $X$ for breach of contract, a court surely will not enforce the agreement as a contract and hold $X$ liable. The court will not make him sell his possessions, garnish his wages, or otherwise hold him liable for his partners' shares of the $\$ 1$ million. If there truly were a contract that the parties expected to be enforced, the court should award these damages. ${ }^{64}$ There is no such contract, however. Whether explained by pointing to custom, to the surrounding circumstances, to what the parties would have thought had they thought about it, or to normal understanding, ${ }^{65}$ there is an expectation that the agreement will not be enforced as a contract would be. Instead, the lottery pooling arrangement is simply an agreement among friends to engage in the social activity of playing a game.

If courts recognized pooling agreements as social engagements, then the agreements would be unenforceable. Theoretically, it makes sense for them to do so, but realistically, such a path is unlikely. The huge amounts of money involved in these cases make them factually distinct from the normal social engagement

64. A reasonable man would have foreseen that the failure to buy the ticket could lead to such damages. Thus, in an action for breach of contract, if there were in fact a contract, the plaintiffs would be entitled to recover these direct damages. Hadley $v$. Baxendale, 156 Eng. Rep. 145, 151 (1854).

65. See supra Part II(C). 
cases faced by courts, and as a result, courts will not be comfortable treating lottery pooling agreements as social engagements. This does not mean that all lottery sharing agreements should be enforceable, however. As with gift promises, the underlying rationale for the unenforceability of social engagements supports the conclusion that lottery pooling agreements should be unenforceable. ${ }^{66}$

\section{UNENFORCEABILITY DUE TO LACK OF RELIABILITY}

As discussed in Section II(B), some agreements to share lottery winnings should be dismissed on a gift promise theory, and as discussed in Section II(D), most pooling agreements should be dismissed as social engagements. Still, the unenforceability of these agreements need not rely on such analogies. Instead, the underlying rationale for the unenforceability of both gift promises and social engagements, their lack of reliability, supports the conclusion that the judiciary should refrain from enforcing agreements to share lottery winnings.

In the gift promise area, the lack of an offer and consideration is the means used to distinguish gift cases from contract cases, but it is not the reason for the distinction. It is simply the tool used to distinguish promises based on underlying public policy grounds. Although it is appealing to think of the judiciary as the champion of all that is good, this tool was not primarily chosen to enforce morality. A promise is a promise, and it would be very difficult to argue that one has a greater moral duty to fulfill a promise given in exchange for consideration than one given without consideration. ${ }^{67}$

66. See infra Part III.

67. Compare, for example, a case in which one person offers to sell his bike to another person and the other person accepts (a return promise that certainly would be contractually enforceable) with a case in which a father promises to pay back a Good Samaritan who at his own expense rescued and nursed back to health the father's son who had been in a bad accident (a promise that would not be contractually enforceable according to a inajority of courts for lack of consideration). See Mills v. Wyinan, 20 Mass. (3 Pick.) 207 (1825); Harrington v. Taylor, 36 S.E.2d 227 (N.C. 1945). But see Webb v. McGowin, 168 So. 196 (Ala. Ct. App. 1935) (holding minority position that such a promise is enforceable). It would be difficult to argue that the moral obligation to buy a bike is greater than the obligation to pay the costs of an individual who saved someone's life. 
Instead, courts require these contractual elements to distinguish between promises that have a level of reliability that makes judicial enforcement appropriate and those that society considers less reliable. A reliable promise is the type of promise on which a promisor should know his promisee likely will rely and is the type of promise on which society has determined a promisee is justified in relying. ${ }^{68}$ The use of the term "reliable" in this Note is not meant to include evidentiary reliability. Whether or not it is difficult to determine the terms of an alleged promise is irrelevant to the reliability theory presented here.

Promises fall on a spectrum of reliability, with some more and others less reliable. The contractual elements are designed to draw a line on this spectrum such that promises above the line are judicially enforceable while those below are not. For example, a promise by a child to his mother that he will take out the garbage when he gets home from school is on the lower end of the spectrum, while a written promise by IBM to buy computer parts from a supplier in return for the supplier's promise to deliver those goods is on the higher end. Gift promises fall below the line because the usual expectation of gift promisors is that the promisee will not rely on the promise to any great extent and because society has determined that it is inappropriate for gift promisees to rely on such promises.

This reliability theory also explains why social engagements are unenforceable. Although different verbal formulations are used by the authorities to explain this conclusion, ${ }^{69}$ arguably they all mean the same thing. Whether the unenforceability is explained as being based on custom, on surrounding circumstances, on what the parties would have thought had they thought about it, or on normal understanding, the gist is that there is something very different about these promises that makes them unenforceable. Even though the parties to such agreements do not say so explicitly, the courts are willing to assume that they do not wish to be legally bound. By making this assumption, they are in essence deeming these promises unreliable. The assumption made is that the promi-

68. This discussion covers types of promises and not specific promises made by specific promisors. Thus, whether a promise is made by someone who everyone knows is honest or by a known liar is irrelevant to the enforceability of the promise. What matters is what kind of promise it is.

69. See supra Part II(C). 
sor intended that his promisee not rely on his promise, and the act of assuming signifies society's determination that reliance is inappropriate.

The pooling arrangements that engender litigation are similarly unreliable. As discussed above, a court likely would not force a pool member who forgot to buy the winning ticket to pay his fellow pool members the prize amount even if he knows that forgetting to buy the ticket could lead to such a result. A simple promise to engage in a pool activity is like a child's promise to empty the garbage. It is not the type of promise that rises to a level of reliability appropriate for judicial enforcement. On the other hand, in a contract between IBM and a supplier, if the supplier does not deliver on time and thus shuts down IBM's production, the supplier very well may be held liable for a tremendous amount of damages for breach of contract. The reason for the distinction between the enforceability of the pool and the IBM contract is not the foreseeability of the damages involved; it is easily foreseeable that if one forgets to buy a ticket, huge losses could result. Instead, the reason is that IBM should be able to rely on the supplier contract more than the pool members can rely on their friend to buy the ticket. Contract law should give force to this distinction.

It could be argued that while a member of a pool cannot rely on another member of the pool to buy the ticket, he at least can rely on that member to share the winnings if he does in fact buy a winning ticket. In other words, maybe all that pool members expect is that if the other member gets around to buying the ticket, he will share any winnings. By making this assumption, perhaps some sense could be made of requiring the parties to share if the ticket is bought and is a winner, while not holding the designated buyer liable for damages if he forgets to buy a winning ticket.

To do so would corrupt the idea of a contract, however, because it is doubtful that pool members would admit that they expected so little from their pool companion. They would likely claim that when they put in their dollar, they expected that the ticket would be bought and that any winnings would be shared. To give force to one expectation as contractual but not to the other would not make sense. Instead, it is more logical to conclude that these promises made within the lottery pooling context are just not the types of promises that are sufficiently reliable for legal enforceability to be appropriate. These are not the types of promises that promisors intend their promisees to rely on very heavily. 
A likely criticism of this Note's proposal that courts should refrain from enforcing agreements to share lottery winnings is that such a policy would encourage those who possess the tickets in pools to attempt to cheat their partners. There is some truth to this criticism, especially if people continue to engage in such endeavors even though they know courts will not enforce their agreements. It is because of this concern that this Note suggests the radical solution that courts should refuse to enforce only unwritten pooling agreements.

As discussed in Section II(C), an intent to be legally bound is not required for an agreement to be enforceable. On the other hand, if one explicitly states that he intends not to be bound, he will not be. With social engagement promises, the existence of an intention not to be bound is assumed. Such an intention not to be bound likewise should be assumed in lottery pooling agreements due to their lack of reliability. However, if this assumption were inappropriate for a specific agreement, the parties involved could signify so by executing a writing. The writing would supply objective evidence that the promisor did not have the intention not to be bound, or in other words that he intended that his promisees would rely on his promise. ${ }^{70}$ It would elevate the agreement on the spectrum of reliability so that a contract would be created.

This suggestion is radical because there are no other agreements that are treated this way for this reason. Under the Statute of Frauds, ${ }^{71}$ there are types of agreements that are enforceable only if in writing, but the reason for the requirement in those cases is evidentiary. ${ }^{72}$ In lottery pooling cases, the purpose of the requirement would be to establish reliability, not to create evidence. Defining written pooling agreements as enforceable would signal to a potential promisor that he should expect reliance on his written promise ${ }^{73}$ and that because he should expect reliance, he

70. A beneficial evidentiary byproduct would result from such a requirement. It would be difficult to argue that a pooling agreement did not exist if there were a directly contrary writing.

71. The Statute of Frauds, an English statute enacted in 1677, was generally copied by, and is in force in, all of the United States except Louisiana. RESTATEMENT (SECOND) OF CONTRACTS ch. 5 statutory note, at 281-83 (1979). The statute forbids the enforcement of certain types of agreements unless memorialized in a written memorandum. Id. $\S 110$.

72. The purpose of the Statute of Frauds has been "to provide reliable evidence of the existence . . of the contract." Id. at 286.

73. Such a result obviously depends on whether the average lottery player is made 
should fully consider the implications of entering into a contract. Further, because this writing requirement would serve this cautionary purpose, society would deem it appropriate for a promisee to rely on the resulting thoroughly considered promise.

Once again, as with the above argument that lottery pooling agreements should be analyzed as social engagements, it is unlikely that courts will follow this proposal. The proposal requires two giant leaps. First, it requires the courts to assume an intent not to be bound to unwritten lottery pooling agreements despite the presence of the normal contractual elements of an offer, acceptance, and consideration. Second, it requires the courts to assume no such intent not to be bound if the parties have executed a writing. It is unlikely that courts will be willing to create such an assumption in this one specific area. The normal contractual elements draw a bright line and are easy to apply, and courts will not readily assume that these elements are not drawing the proper line on the reliability spectrum. Nevertheless, this Note suggests that they should do so.

\section{CONCLUSION}

While agreements to share lottery winnings could be dismissed if likened to gift promises or social engagements, the unenforceability of these agreements does not rely on such analogies. Instead, on a more fundamental level, these agreements should not be enforced for the same underlying reason that gift promises and social engagements are not enforced, namely their lack of reliability. The reliability of these promises could be established, however, if a writing were required before a court would enforce them. Creating such a requirement is a step courts should take, and if they will not, state legislatures should. ${ }^{74}$

aware of this requirement. Numerous methods could be used to accomplish this, including requiring lottery ticket distributors to post signs explaining the law and mandating the addition of a legend on the tickets themselves.

74. Although no state yet requires such a writing, it is encouraging that state lottery officials at least have begun to encourage pools to produce written agreements. See, e.g., Frank Donze, Lottery Players Dive in Pool, Hope to Be Awash in Cash, TIMEs-PICAYUNE, Jan. 9, 1993, at A1 (discussing Louisiana Lottery Corporation's encouragement of a writing); Groups Should Sign Pact on Lottery Winnings, MiNNEAPOLIS STAR TRIB., Oct. 16, 1991, at 9E (discussing Minnesota Lottery officials' encouragement of a writing). 